\title{
MORPHOLOGICAL AND ANATOMICAL STRUCTURE OF GENERATIVE ORGANS OF SALSOLA KALI SSP. RUTHENICA (ILJIN) SOÓ AT THE SEM LEVEL
}

\author{
KRYSTYNA IDZIKOWSKA \\ Laboratory of Electron Microscopy \\ Faculty of Biology, Adam Mickiewicz University \\ Umultowska 89, 61-614 Poznań, Poland \\ e-mail: IKa@main.amu.edu.pl
}

(Received: September 23, 2004. Accepted: January 15, 2005)

\begin{abstract}
The morphology and anatomy of generative organs of Salsola kali ssp. ruthenica was examined in detail using the light (LM) and scanning electron microscopy (SEM). The whole flowers, fruits and their parts (pistil, stamens, sepals, embryo, seed) were observed in different developmental stages. In the first stage (June), flower buds were closed. In the second stage (August), flowers were ready for pollination/fertilization. In the third stage (September), fruits were mature. Additionally, the anatomical and morphological structure of sepals was observed by means of LM and SEM. Thanks to the transverse and longitudinal semi-sections through sepals, the first phase of wing formation was recorded by SEM. The appearance of stomata in the epidermal cells of sepals above the forming wings was very interesting, too. The stomata were observed also in mature fruits.
\end{abstract}

KEY WORDS: Chenopodiaceae, Salsola kali ssp. ruthenica, flower, parts of flower, sepals, fruit, semi-sections, SEM.

\section{INTRODUCTION}

The genus Salsola (Chenopodiaceae) is a cosmopolitan group of plants, which have become naturalized on all continents. They are the most common in central and western regions of Europe, Eurasia, Canada and the United States. Members of this genus are found in most arid and semiarid regions of the world. These plants colonize disturbed sites, sandy soil, wastelands and roadsides. The scientific name of Salsola derives from the Latin sallere, which in English means to salt, in reference to the plants' salt tolerance (Reimann et al. 1995).

In Poland the genus Salsola is represented by two species: S. collina Pall. and S. kali L. (Baradziej 1972; Mądalski 1960; Stengl-Reithar 1992; Balcerkiewicz et al. 1990; Kornaś 1953; Żukowski et al. 1995). S. kali L. has two subspecies in Poland: S. kali ssp. kali and S. kali ssp. ruthenica (Iljin) Soó. The two subspecies differ in the habitats occupied by them. S. kali ssp. kali is found naturally in more or less saline littoral habitats along the Baltic Sea (Klimko 1975), while S. kali ssp. ruthenica is found inland. It has been recorded at about 100 locations in Poland, and the plant is fairly numerous at each of them (Baradziej 1972; Balcerkiewicz and Pawlak 1990; Żukowski et al. 1995).
The objective of this study was to analyse the morphology and anatomy of generative organs of the inland variety of $S$. kali with the use of scanning electron microscopy (SEM) and light microscopy (LM).

\section{MATERIAL AND METHODS}

The plants were collected throughout their growing period: since June to September. The plants grew in their natural habitats - on disturbed sites along railway lines near the city of Poznań (Poland). The examined material ranged from early stages of flower development (closed buds) to the end of fruit development.

Whole flowers and fruits or their parts (pistil, stamens, sepals, seed, embryo) were fixed with $3 \%$ glutaraldehyde in $0.1 \mathrm{M}$ sodium cacodylate buffer, at $\mathrm{pH} 7.2$ for $24 \mathrm{~h}$ at room temperature. Primary fixation was followed by postfixation in $1 \%$ osmium tetroxide in the same buffer. After fixation the samples were dehydrated in a graded series of ethanol/acetone solutions (10\% steps, $10 \mathrm{~min}$ per step), followed by critical point drying with carbon dioxide as the transitional fluid. Samples were mounted on stubs and coated with gold by using a sputter coater. Some material was embedded in an epoxy resin (Epon 812). 

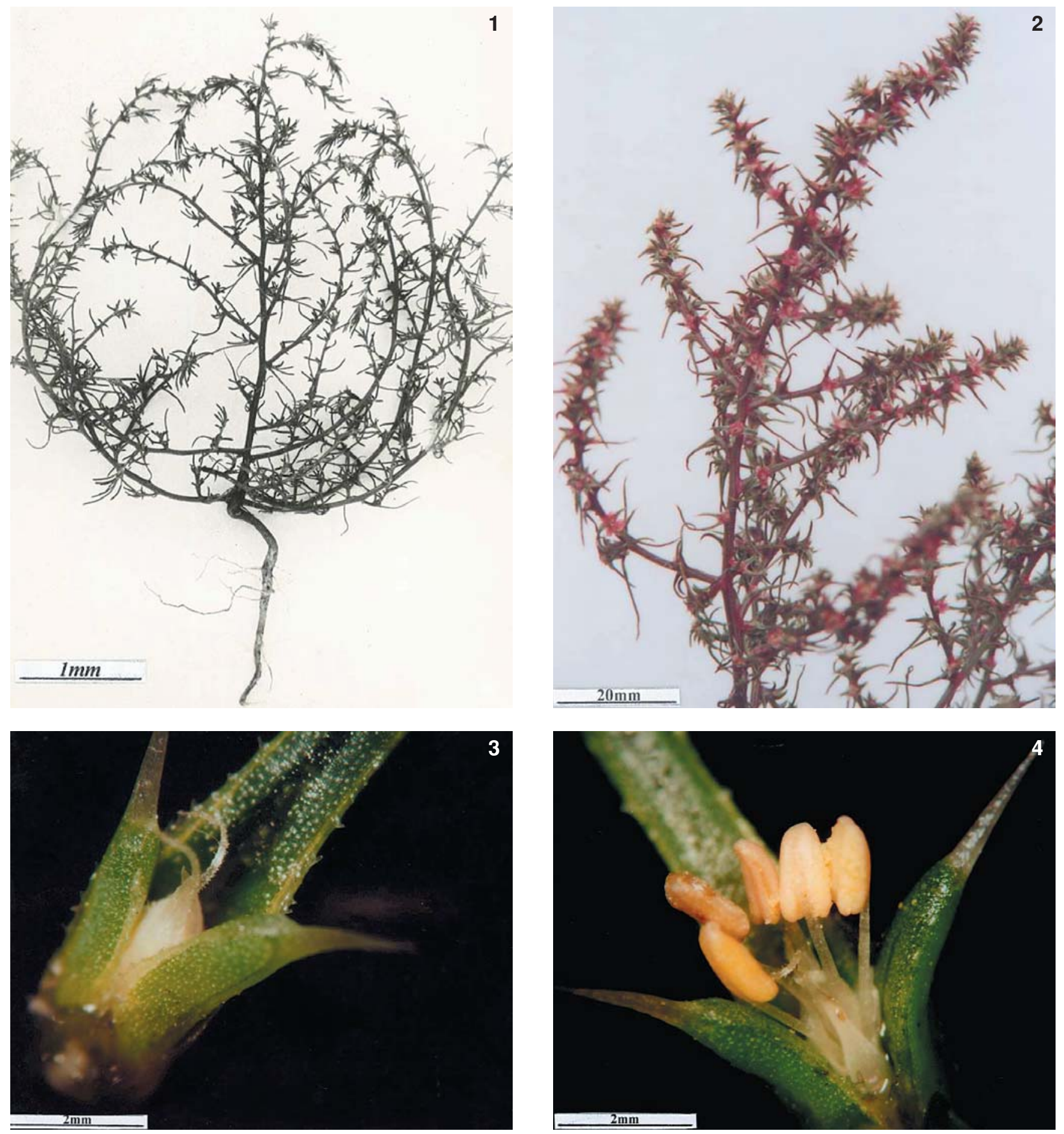

Salsola kali ssp. ruthenica - general habit and flowers

Fig. 1. Young plant.

Fig. 2. Twig with numerous flowers

Fig. 3. Flower in the first developmental stage (closed bud): stigma visible above the bud.

Fig. 4. Flower in the second developmental stage (pollination/fertilization). 

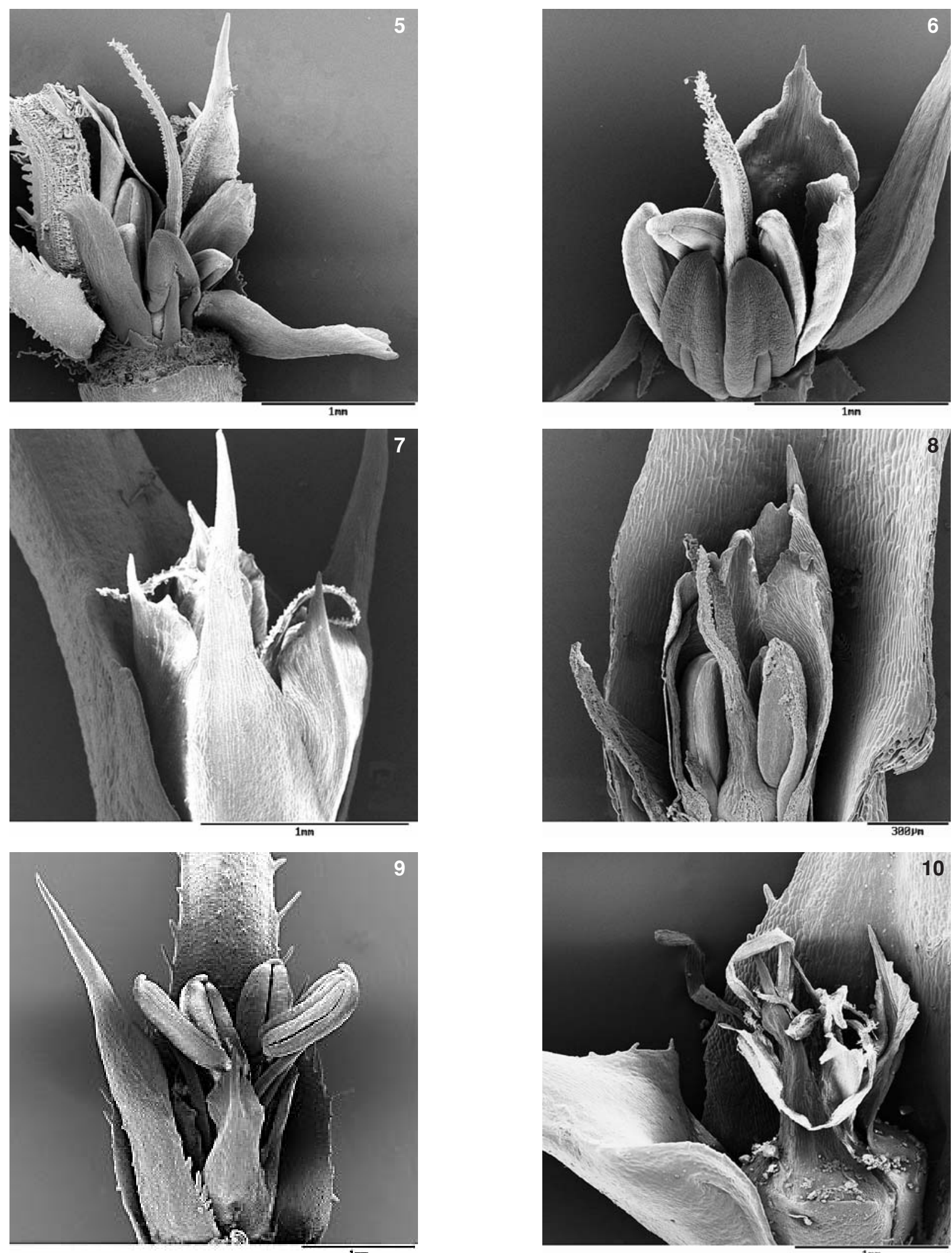

$1 m$

$1 \mathrm{~mm}$

Salsola kali ssp. ruthenica - flowers in various developmental stages

Fig. 5. Flower in the first developmental stage (closed bud): stamens immature, pistil mature.

Fig. 6. Flower in a later developmental stage: stamens immature, pistil mature.

Fig. 7. Flower in the pollination/fertilization stage: clearly visible spine-like ends of three larger sepals.

Fig. 8. Cross-section through the flower in the bud stage: stamens and pistil develop simultaneously here.

Fig. 9. Flower with mature stamens, stigma invisible.

Fig. 10. Flower after fertilization, developing into a fruit. 

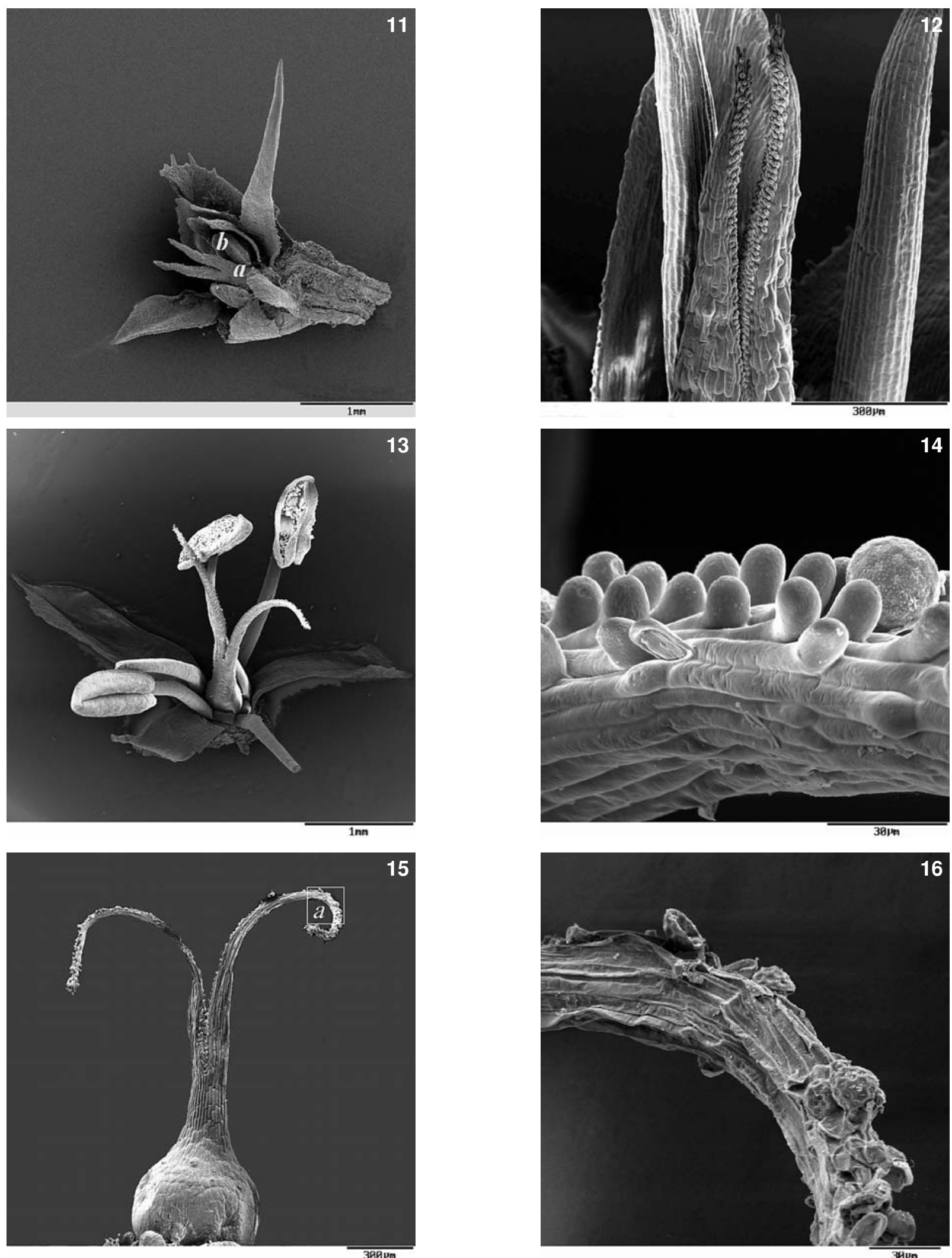

Salsola kali ssp. ruthenica - pistil in various developmental stages

Fig. 11. The inside of a very young flower: the stigma divided into two parts, stamens immature.

Fig. 12. Two young arms of the stigma.

Fig. 13. Flower in the pollination stage: anthers in various developmental stages (some immature).

Fig. 14. Pollen grain among small papillae on the stigma surface.

Fig. 15. Pistil after fertilization.

Fig. 16. Magnified fragment $a$ from Fig. 15: degenerated stigma and pollen grains. 

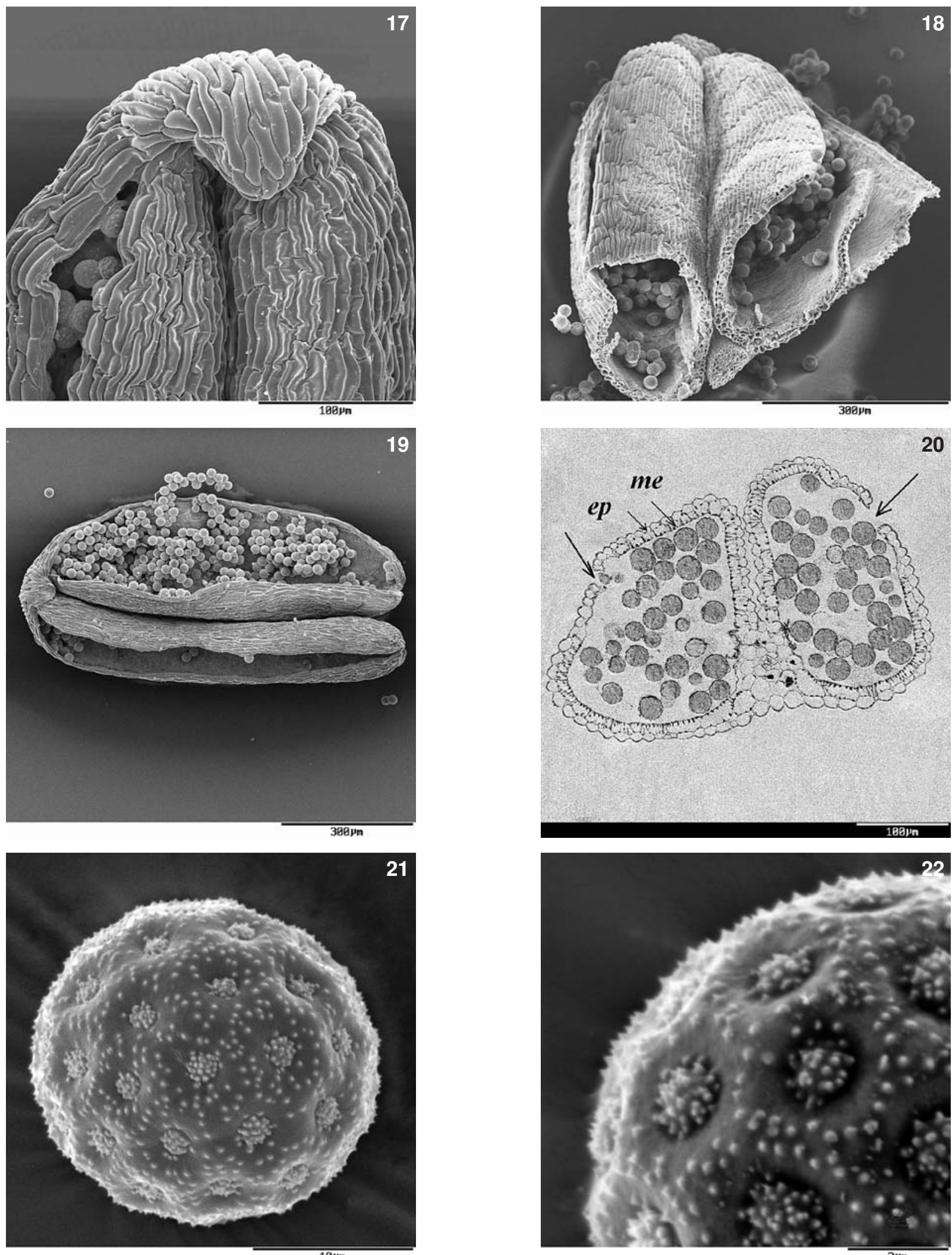

$3 \mu \mathrm{n}$

\section{Salsola kali ssp. ruthenica - anthers and pollen grains}

Fig. 17. Upper part of the anther: the interior of the pollen sac visible on the left.

Figs 18 and 19. Ripe pollen sacs with numerous pollen grains.

Fig. 20. Transverse semi-section of two pollen sacs: arrows show places of dehiscence ( $e p$ - epidermal cells; $m e$ - mature endothecium).

Fig. 21. Pollen grain with numerous pores (apertures).

Fig. 22. One quarter of the pollen grain. 

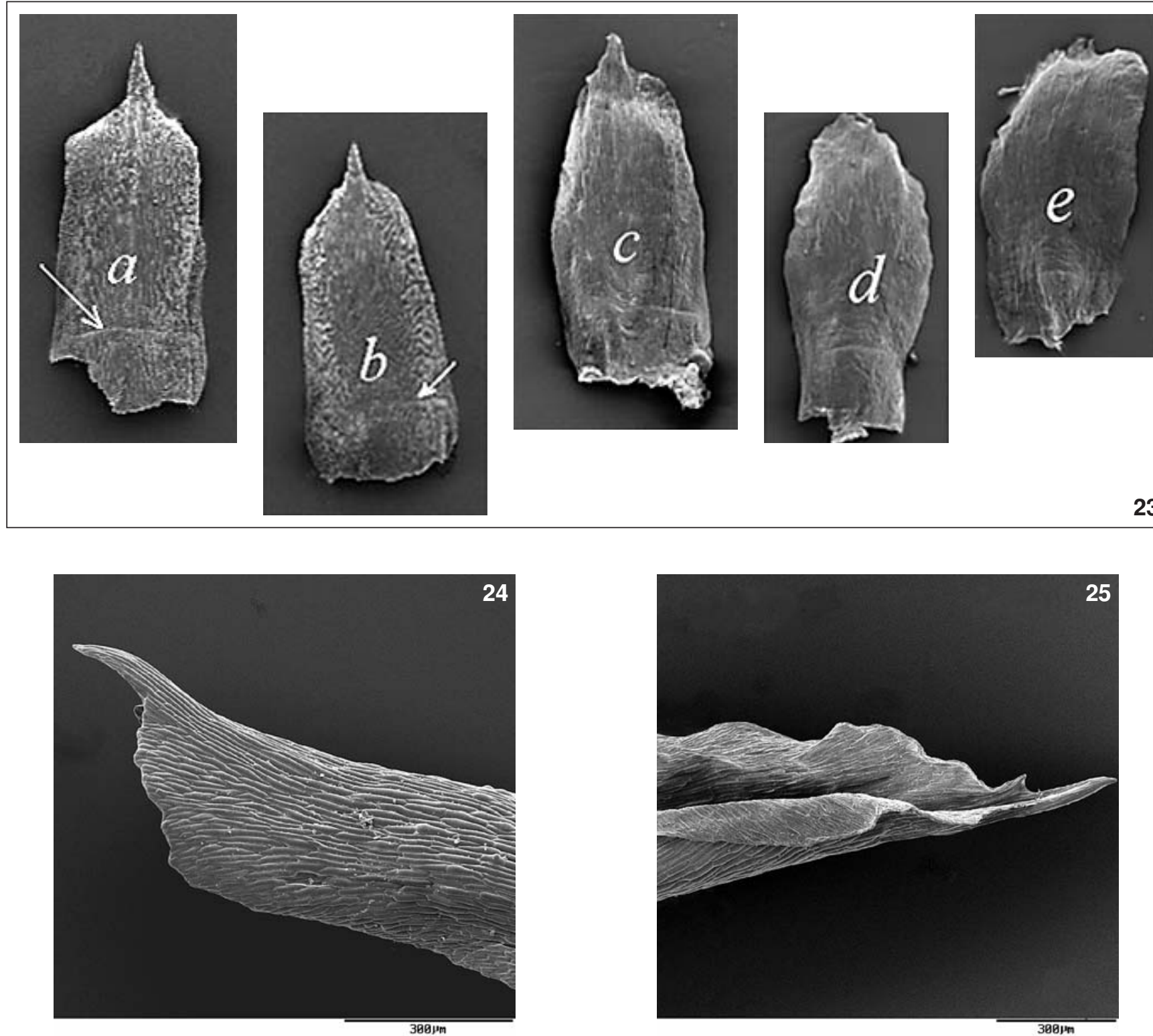

Salsola kali ssp. ruthenica - sepals

Fig. 23. Five sepals of one flower in the early developmental stage (close bud): $a, b, c$ - larger sepals (1.7 to $2.0 \mathrm{~mm}$ long); $d, e-$ smaller sepals (1.4 to 1.6 $\mathrm{mm}$ long). Arrows mark the places where the wings will be formed (the thin white line).

Figs 24 and 25. Spine-like ends of larger sepals: Fig. 24 - abaxial surface; Fig. 25 - adaxial surface.

The embedded stamens and sepals were cut on an ultramicrotome (Ultracut S, Reichert) into transverse or longitudinal semi-sections ( $2 \mu \mathrm{m}$ thick). These sections were placed on SEM stubs and coated with gold, too. Materials prepared like this were observed and photographed with a Philips 515 scanning electron microscope, equipped with a Digital Image Scanning System (DISS), at an accelerating voltage of $7.5 \mathrm{kV}$. Some objects were photographed at the light microscopic level, too.

\section{RESULTS}

General description of Salsola kali ssp. ruthenica (Iljin) Soó

Specimens of Salsola kali ssp. ruthenica were collected along railway lines north-west of Poznań. They formed there a small isolated population on gravelly grey-brown soils. The plants are short $(30-40 \mathrm{~cm})$ annuals, strongly and intricately branched and rounded in form (Fig. 1). The immature plants are wider than tall, as the main stem is shorter than lateral branches (Fig. 1). The green stems are rigid, typically curved upwards, usually striped, with red lines. The stems and leaves are succulent when young but woody at maturity.

The dark green leaves are alternate, glabrous, fleshy, thick, stiff, spine-tipped (6-40 mm long, 1-1.5 mm wide), often curved away from the stem (recurved) near the tip.

The paired bracts (Figs 3,4) situated below each flower adhere to the stem and strongly overlap it. The bract is reflexed and has a membranous, minutely toothed margin (Fig. 3).

The taproot has numerous lateral roots (Fig. 1).

Salsola kali ssp. ruthenica flowers from July to August. The tiny pink flowers are clustered at the axils of leaves along the branches (Fig. 2). The flowers are numerous, bi- 

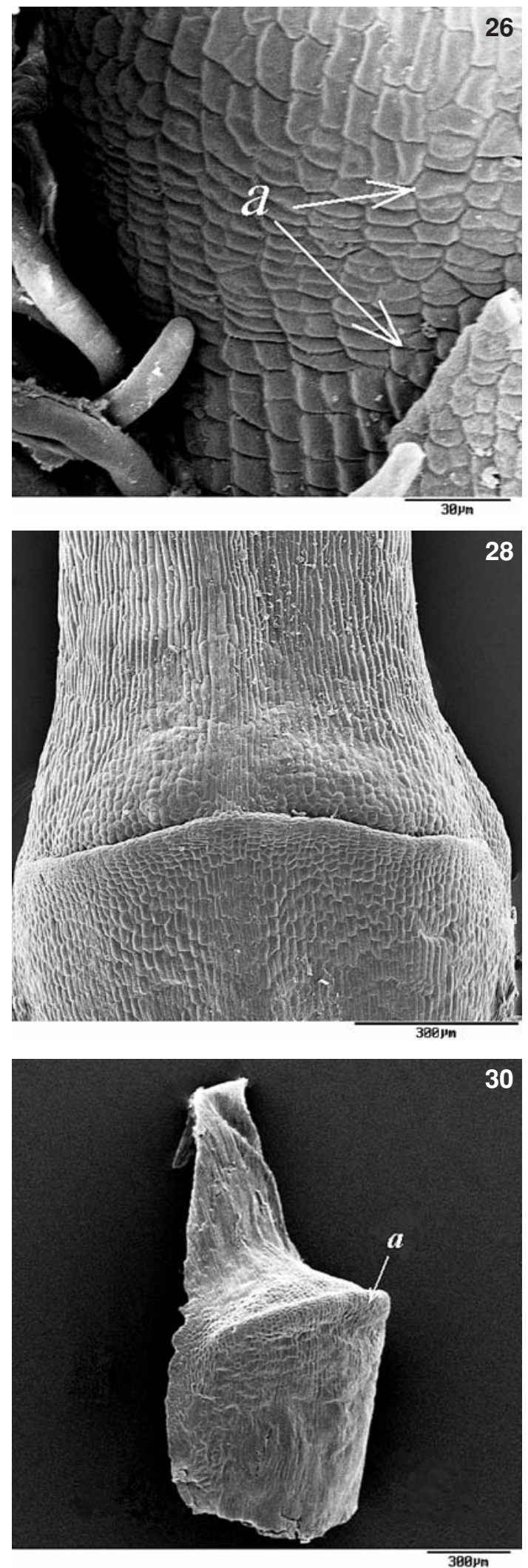

30
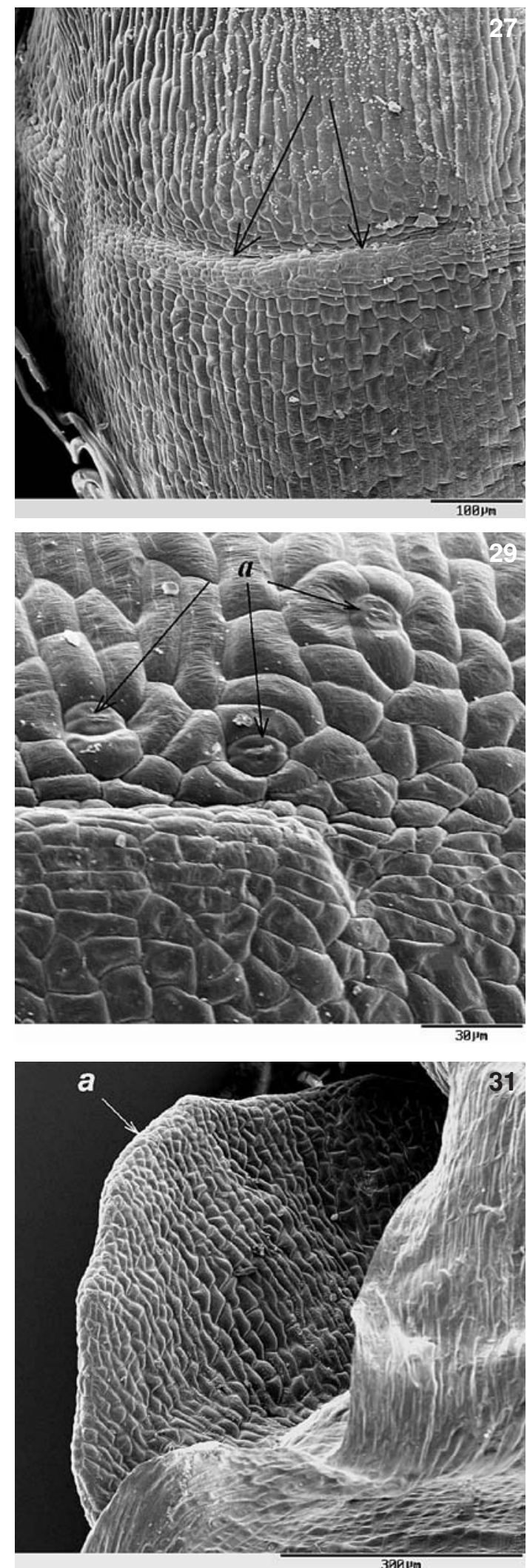

Fig. 26. The first sign of wing development: the meristematic zone $(a)$.

Figs 27-31. Successive stages of wing formation.

Fig. 29. Stomata $(a)$ above the young wing. 

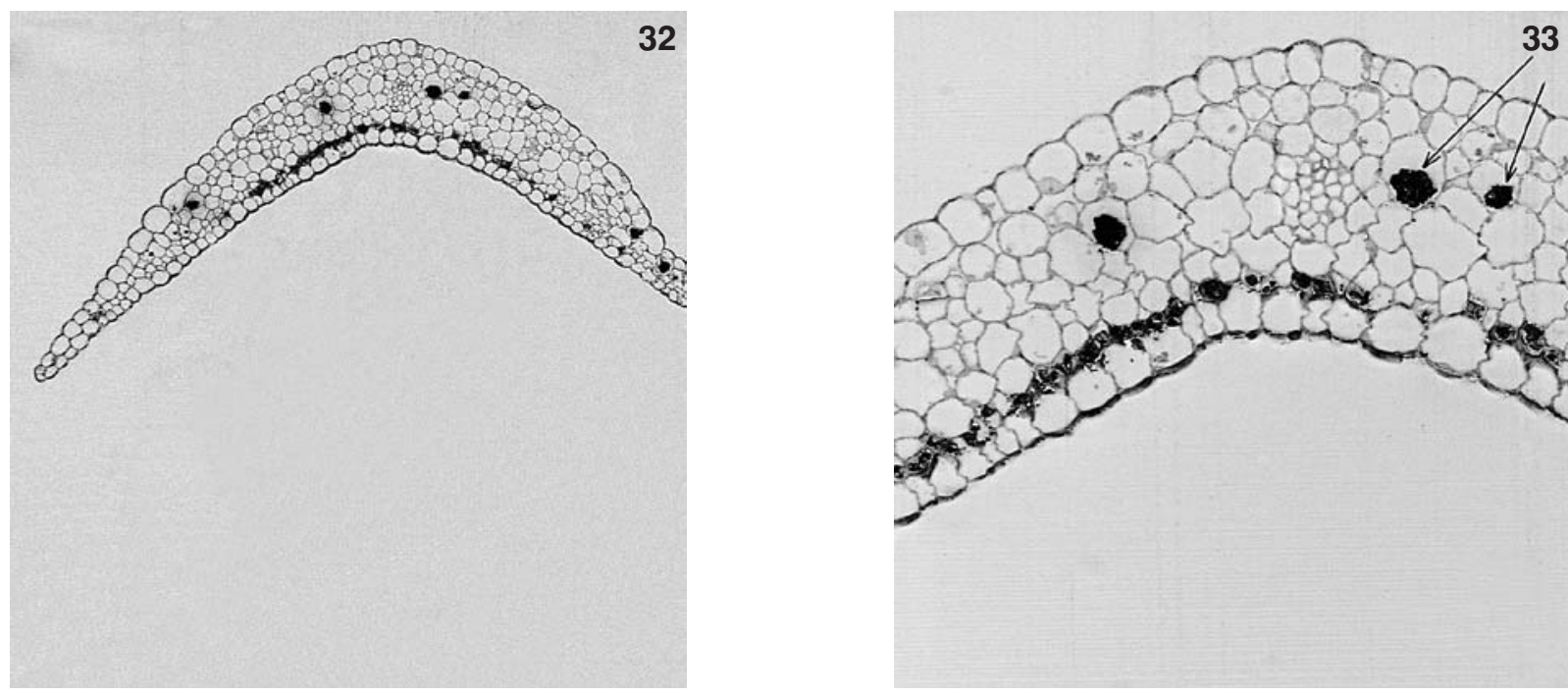

34
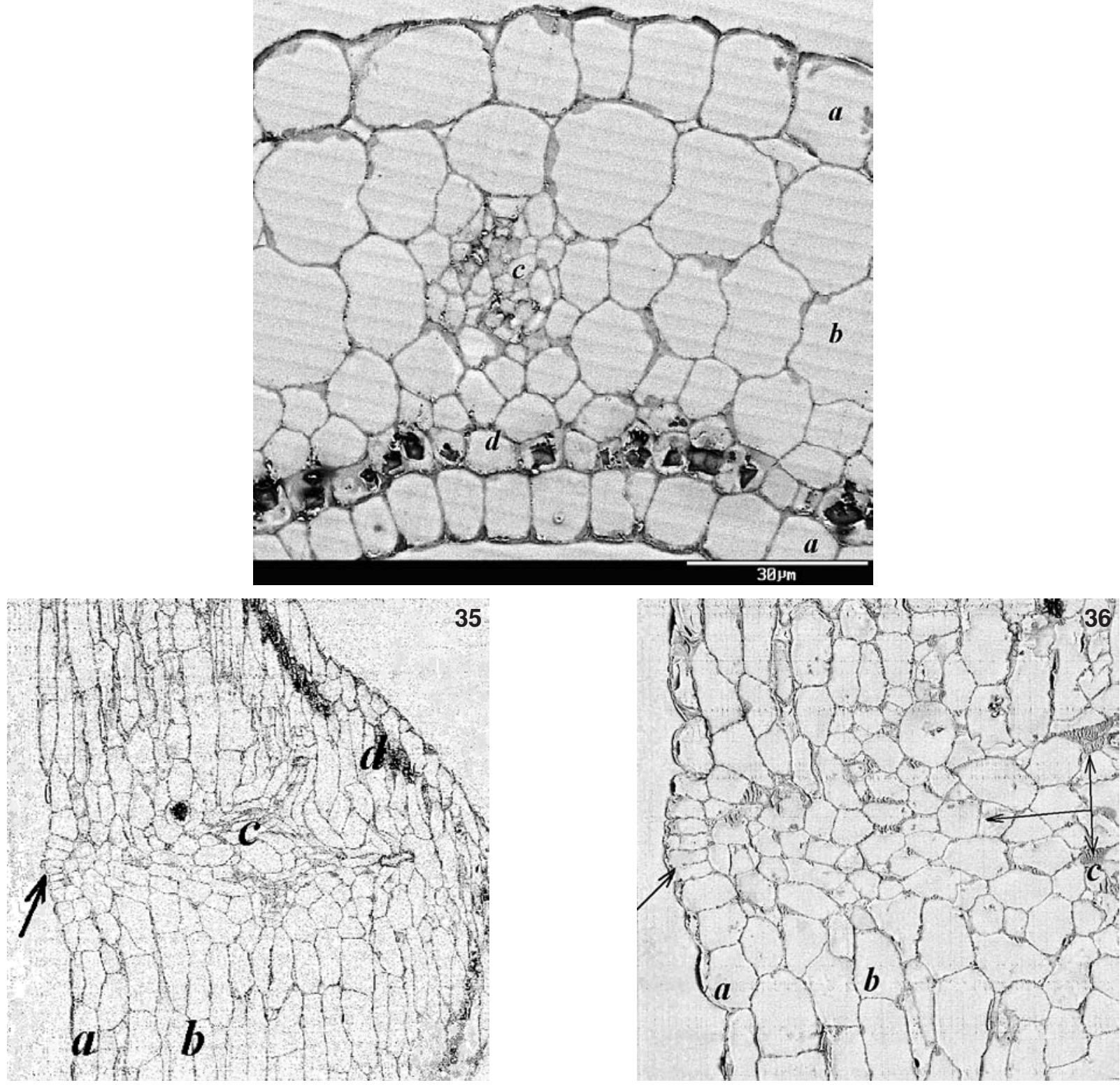

Salsola kali ssp. ruthenica - transverse and longitudinal semi-sections of the middle part of a young sepal below the wing

Figs 32 and 33. Transverse semi-sections of the middle part of a sepal below the wing. Arrows show crystals inside parenchyma cells.

Fig. 34. Middle part of a semi-section across the sepal: $a$ - epidermal cells on adaxial and abaxial side; $b$ - parenchyma cells; $c$ - vascular bundle; $d$ - pigmented cells.

Figs 35 and 36. Longitudinal semi-sections of young sepals (closed bud): $a, b, c, d$ - as in Fig. 34. Arrows show places of wing development. 


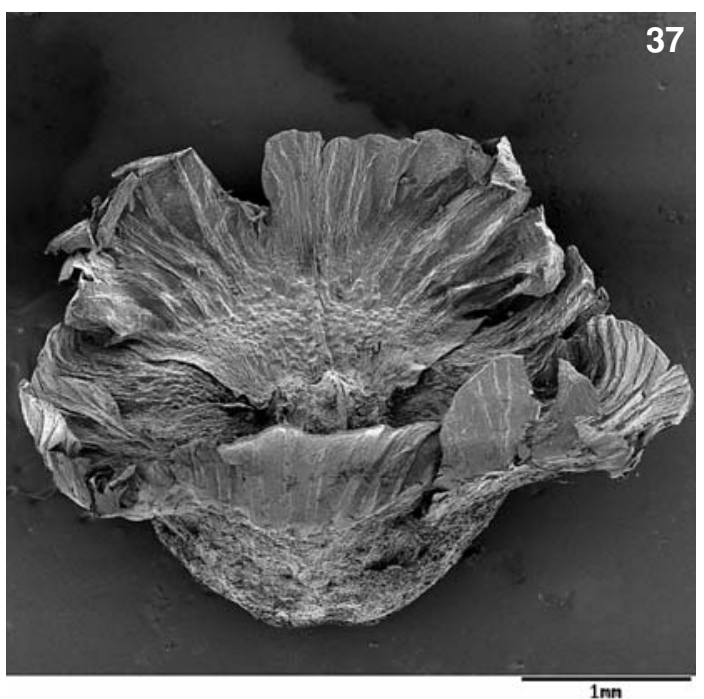

$1 \mathrm{mn}$
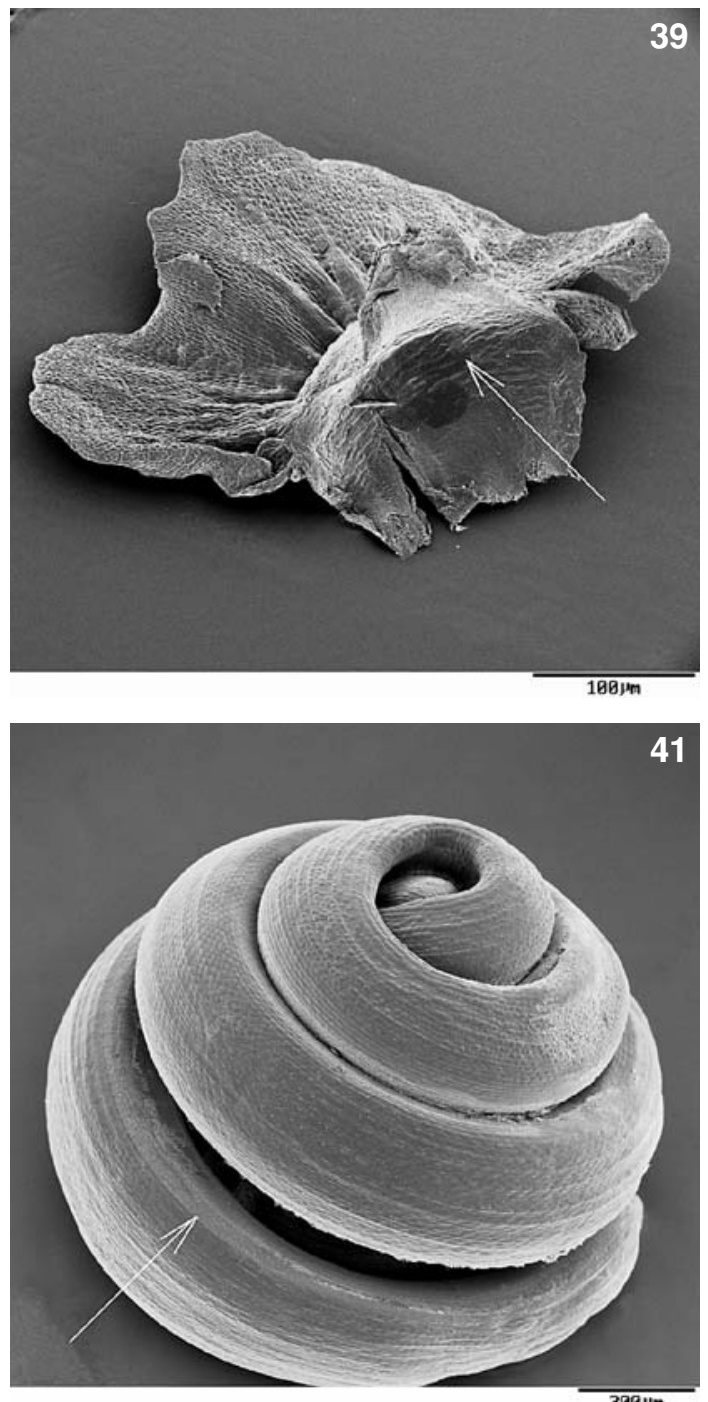

41

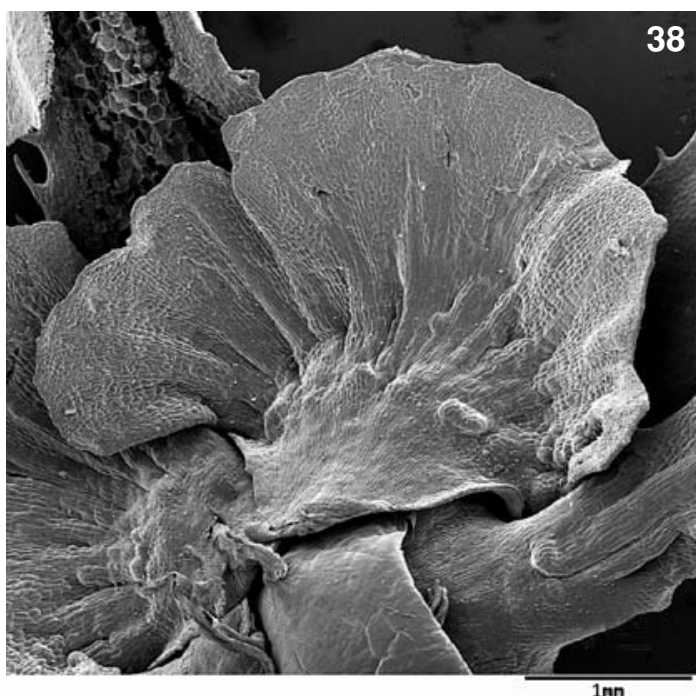

$1 \mathrm{mn}$
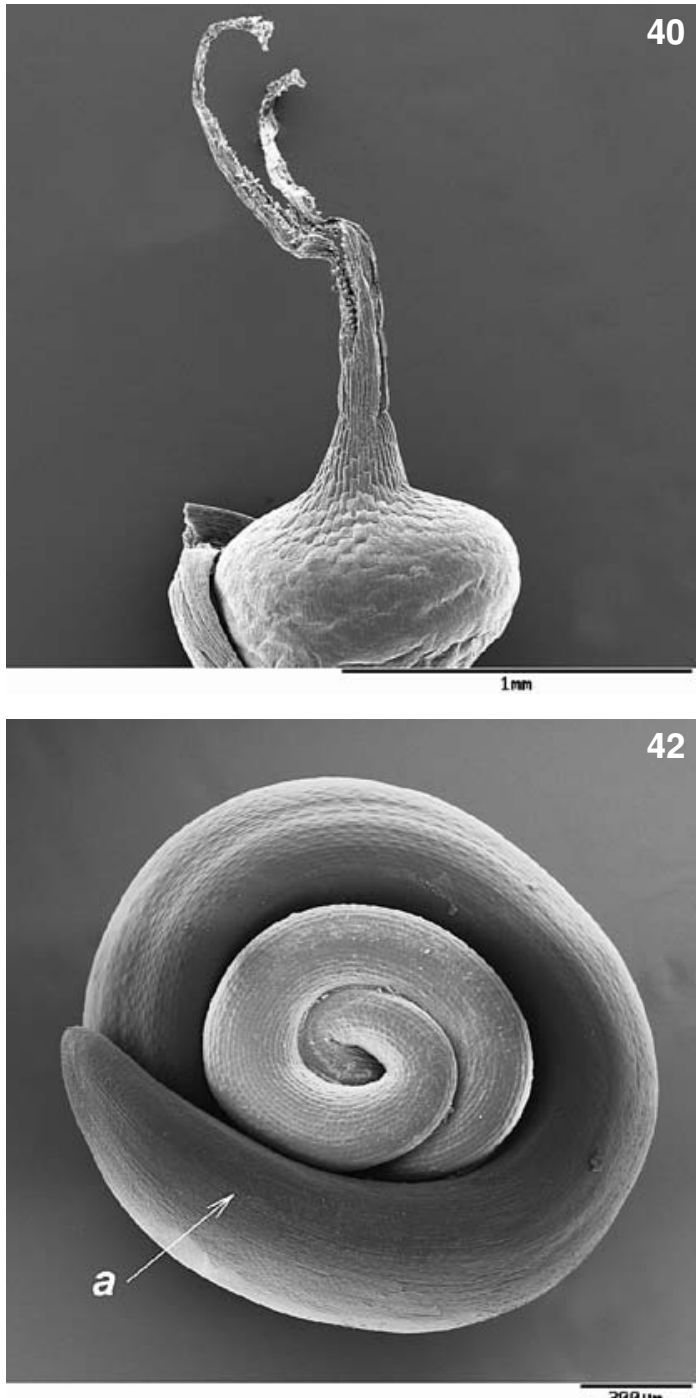

$300 \mathrm{pm}$

Salsola kali ssp. ruthenica - fruit, fruit coat, seed and embryo

Fig. 37. Mature fruit, about $4 \mathrm{~mm}$ in diameter (with the wing).

Figs 38 and 39. Two larger parts of the fruit coat (sepal wings). The arrow shows the internal surface of the wing.

Fig. 40. The seed at an early developmental stage.

Fig. 41. The embryo - upper side. The arrow shows cotyledons.

Fig. 42. The embryo - lower side. The arrow shows the radicle. 
sexual, wind-pollinated, cross-pollinated or self-pollinated. The flower of Salsola is incomplete, lacking one of the main floral whorls - petals. There are only five sepals, persistent in fruit, typically with wing-like appendages that appear petal-like. The sepals have a leaf-like appearance and are pink (Figs 2,4). The sepals play a key role in protecting the inner structures of the bud by covering them. As the blossom opens, the sepals reveal the more conspicuous parts of the flower - stamens and pistil. The five stamens are initially located just inside the flower. Each of them is composed of a filament and anthers that have four pollen sacs with numerous pollen grains.

The single pistil is located in the middle of the flower. The ovary contains one ovule, which develops into a seed. The seeds are unusual in that they lack any protective coat or stored food reserves. The fruit is a utricle surrounded by five enlarged sepals, each developing into a fan-shaped, strongly veined wing.

\section{Detailed description of flower parts in SEM Pistil}

The pistil (Figs 11-13) is composed of an ovary with one embryo sac, a short style, and distal stigma. In the earliest stage (closed bud) the stigma is divided into two erect arms standing side by side (Figs 11, 12). During pollination the distance between the arms of the stigma increases and their upper parts curve back (Fig. 13). The surface of the internal side of the arms is covered with numerous slender and short papillae (Fig. 14), which during pollination become longer than broad. The stigma is dry, serving as the landing platform for pollen grains (Fig. 14).

During pollination the arms of the stigma are about 2.5 times as long as the ovary (Fig. 13). After fertilization, the stigma starts to shrink and die, while papillae and pollen grains disappear (Fig. 16).

\section{Stamens, anthers, and pollen grains}

Salsola kali ssp. ruthenica has five typical stamens differentiated into anthers, filament and connective tissue (Figs $5,6,8,13)$. In the first stage (closed buds), the small but well-developed stamens are located at the bottom of the flower and face the pistil (Figs 5, 6). Their filaments are very short and relatively thick. During flower development, the filaments quickly grow and become very long. Thanks to this increase, the anthers are visible above other parts of the flower during pollination (Figs 4, 9, 13). The anthers become larger. The mature anther comprises four pollen sacs joined by the connective tissue to the filament (Figs 4,9 ) and on top connected with a curved appendage (Fig. 17).

The wall of the mature pollen sacs is two-layered (Fig. $20)$, composed of the epidermis (ep) and mature endothecium (me). The interior of the pollen sacs is filled with huge numbers of pollen grains (Figs 13, 18-20). When the pollen grains ripen, the rupture of pollen walls begins at the stomium. The stomium is the point at which rupture occurs in a pollen sac to release pollen. The rupture begins first on top of the anther between the pairs of the pollen sacs (Fig. 17 ) and proceeds along the whole anther (Figs 13, 18, 19).

The transverse section through the pollen sacs shows the place of rupture (Fig. 20: arrows). Only the epidermis reaches the stomium, as the endothecium ends at a distance from it (Fig. 20).
The tissue between the stomium and pollen sacs disintegrates and pollen grains spill out.

The mature pollen grains of Salsola kali ssp. ruthenica are circular, about $20 \mu \mathrm{m}$ in diameter (Figs 21, 22). The exine - the outer pollen wall - has very numerous apertures (pores) of $4.6 \mu \mathrm{m}$ in diameter (Fig. 22). The remaining exine surface of the pollen grains is smooth, with numerous scattered small granules. The same but crowded granules are on the plugs closing the apertures (Fig. 22).

In this form the pollen grains are ready for pollination/fertilization.

\section{Sepals}

The flower of Salsola kali ssp. ruthenica has five small, pinkish structures named sepals (Fig. 23a-e) but lacks petals. In the early developmental stage of the flower (closed buds) the sepals protect the pistil and stamens (Figs 5, 7, 8 ). The sepals are very delicate, translucent, varying in size and shape: three of them are larger, usually spine-tipped, and two are smaller, with a blunt apex (Fig. 23a-e). On the abaxial surface of the sepals is a light streak, near the base, which is the place where the wings will develop (Fig. 23a: arrow). In the pollination/fertilization stage, the sepals grow and the larger ones develop the spine (Figs 24, 25).

The process of wing formation on the sepal is shown in Figures 26-31. The earliest signs of wing formation are observed in the closed bud, when the streak composed of meristematic cells appears (Fig. 26a: arrows). During wing formation, a very interesting phenomenon can be noticed. On the abaxial side, above the newly formed wing, stomata developed (Fig. 29). They were visible in this place also when the fruits were mature.

The transverse semi-sections through young sepals below the wing (Figs 32-34) show two layers of epidermal (a) cells on abaxial and adaxial surfaces, separated by parenchyma $(b)$. The main vascular bundle $(c)$ occupies the central section (Fig. 34). The epidermal cells strictly adhere to one another. The parenchyma cells are isodiametric, varying in size, and their cells strictly adhere to one another, too. Large crystals are visible inside some parenchyma cells (Fig. 33: arrow). Apart from them, transverse semi-sections show many smaller crystals inside the pigmented layer $(d)$ near the adaxial epidermal cells (Fig. 34).

The longitudinal semi-sections through young sepals (Figs 35, 36) show the places where the meristematic cells start to form the wing (Figs 35, 36: arrows). Some sections show the pigmented layer (Fig. 35) and the vascular tissue, which branches in the direction of the wing (Figs 35, 36).

\section{Fruit, seed and embryo}

The pistil forms the fruit. After fertilization the anthers and stigma wither and drop off the flower.

The mature fruit develops from the ovary wall (pericarp) with the enclosed seed (Figs 10, 37). The fruit is hidden under the two large fleshy spine-tipped bracts (Fig. 10). It is a vertical utricle, surrounded by the five enlarged sepals, each developing a fin-shaped, strongly veined wing on its back. The larger sepals are connected with the seed, so the internal surface of the wing looks like a replica of the outer surface of the seed (Fig. 39: arrow). The upper surface of the wing is so beautifully formed that the mature fruit looks like a flower (Fig. 37). 
The seed of Salsola kali ssp. ruthenica is rounded in outline and slightly flattened on top (Fig. 40), and contains the coiled embryo, which is dark greenish or brown (Figs $41,42)$. The embryo is wrapped in a thin membrane and is deprived of food reserves. The embryo uncoils as soon as the temperature and moisture are suitable. In fact each seed is just an embryonic plant of the next generation.

\section{CONCLUSIONS}

1. The flowers of Salsola kali ssp. ruthenica are typically wind-pollinated (anemophilous). They have no petals, the stamens have long, thin filaments, which shake in the wind (so they are easily emptied in the wind), and anthers produce vast numbers of pollen grains (to ensure that they get on a stigma). The stigma has two long arms with numerous papillae to catch pollen as it blows by. The pollen grains are very small so they are easily carried away by the wind. Since pollination is no direct, wind-pollinated plants must produce lots of pollen.

2. The flower has five small sepals: three of them are larger and two are smaller. In the closed bud stage the sepals protect other parts of the flower, whereas in the mature flower they protect the seed. The first sign of wing formation on sepals was observed already in the closed bud stage. It is very interesting phenomenon that stomata cells became visible on the abaxial side of the sepals above the newly formed wing only. The stomata can be noticed in this place also when the fruit is mature.

3. The fruit is an utricle. It is surrounded by five enlarged sepals with wings strongly connected with the fruit. The fruit contains one seed, which is rounded and slightly flattened on top.

4. The seed is deprived of food reserves and it is just an embryonic plant of the next generation.

\section{ACKNOWLEDGMENTS}

I am grateful to Prof. Karol Latowski (Department of Plant Taxonomy, Adam Mickiewicz University, Poznań), who collected and identified the plant material used in this study.

\section{LITERATURE CITED}

BALCERKIEWICZ S., PAWLAK G. 1990. Zbiorowiska roślinne zwałowiska zewnętrznego Pątnów-Jóźwin w Zagłębiu Węgla Brunatnego. Badania Fizjograficzne nad Polską Zachodnią. Ser. B. Botanika 40. (in Polish with English summary)

BARADZIEJ E. 1972. Rozmieszczenie rodzaju Salsola L. w Polsce. Disribution of Genus Salsola L. in Poland. Fragmenta Floristica et Geobotanica Ann. XVIII, Pars 3-4. (in Polish with English summary)

KLIMKO M. 1975. Zróżnicowanie ekologiczne roślin plaży i wydm białych Słowińskiego Parku Narodowego w oparciu o cechy budowy anatomicznej. Badania Fizjograficzne nad Polską Zachodnią. Vol. XXVIII, Ser. B. Botanika. (in Polish with English summary)

KORNAŚ J. 1954. Niektóre interesujące rośliny synantropijne znalezione w południowej Polsce w latach 1939-1952. Fragmenta Floristica et Geobotanica, 1 (1): 32-41. (in Polish with English summary)

MĄDALSKI J. 1960. Atlas flory polskiej i ziem ościennych. Vol. VII, no. 2. Chenopodiaceae (pars 2). Ed. Instytut Botaniki PAN, Kraków. (in Polish)

REIMANN C., BRACKLE S.W. 1995. Salt tolerance and ion reactions of Salsola kali L.: differences between ssp. tragus (L.) nyman and ssp. ruthenica (Iljiin) Soó. New Physiol. 130: 37-45.

STENGL-REITHAR A. 1992. "Salsola L.". In: Flora polski - rośliny naczyniowe. Jasiewicz A. (ed.), Vol. III, pp. 210-211. Ed. Instytut Botaniki im. W. Szafera, PAN, Kraków. (in Polish)

ŻUKOWSKI W., LATOWSKI K., JACKOWIAK B., CHMIEL J. 1995. Rośliny Naczyniowe Wielkopolskiego Parku Narodowego. Prace Zakładu Taksonomii Roślin UAM. (in Polish with English summary) 